ELECTRONIC LETTER

\title{
Significant involvement of CCR2-64l and CXCL12-3a in the development of sporadic breast cancer
}

\section{A Zafiropoulos, N Crikas, A M Passam, D A Spandidos}

J Med Genet 2004;41:e59 (http://www.jmedgenet.com/cgi/content/full/41/5/e59). doi: 10.1136/JMG.2003.013649

$\mathrm{T}$ he molecular biology of cancer is still far from being understood, with the exception of specific familial cases.

Amplifications of oncogenes and alterations in tumour suppressor and detoxification genes by mutations or deletions appear especially important in the development of sporadic breast tumours. ${ }^{1-3}$

Tumour infiltrating lymphocytes (TILs) and tumour associated macrophages are thought to play a crucial role in tumour immune surveillance and possibly development. The activation and recruitment of lymphocytes is regulated by chemotactic and proinflammatory chemokines such as RANTES (CCL5), MCP-1, and to a lesser extent MIP- 1 alpha, MIP-1 beta, and IL-8. ${ }^{4-7}$ It has been suggested that melanoma cells evade immune surveillance through the induction of TIL cell death by SDF-1 alpha (CXCL12) and RANTES. ${ }^{8}$ MCP- 1 is the natural ligand of the CCR2 chemokine receptor, expressed mainly in the monocytes, activated $\mathrm{T}$ lymphocytes, and memory cells, ${ }^{9}$ whereas RANTES is the ligand of CCR5. ${ }^{10}$

The relevance of chemokines to malignancy extends beyond leucocyte recruitment. Animal models have shown that chemokine secretion by tumour cells can influence angiogenesis and tumour growth. Expression of angiogenic CXC chemokines by tumour cells in severe combined immunodeficient (SCID) syngenic mice has been shown to enhance tumour growth. ${ }^{11}$ However, the association of any kind of cancer with chemokine related genetic markers has not been examined to date.

We selected the polymorphisms CCR2-64I, ${ }^{12}$ CXCL12-3'A, CCR5 $\Delta 32$, and CCR5 59029 G-A ${ }^{10}{ }^{13}$ because of functional and clinical data from AIDS studies. We determined the genotype for the above four polymorphisms in 442 cancer samples and 361 control samples. Our data indicate a significant involvement of the chemokine system in the development of breast cancer.

\section{MATERIALS AND METHODS \\ Patients and samples}

Breast cancer

Blood samples were collected at the Prolepsis (centre for breast cancer diagnosis and research in Athens, Greece) from 233 female patients with breast cancer, aged 31-79 (average 56) years. Samples were stored at $4^{\circ} \mathrm{C}$ until DNA extraction. In addition, 31 tumour specimens from female breast cancer patients, aged 36-76 (average 56) years, were surgically obtained and stored at $-70^{\circ} \mathrm{C}$ until DNA extraction.

\section{Non-melanoma skin cancer}

Blood samples were collected at the A Sygros Hospital (Athens, Greece) from 110 non-melanoma skin cancer patients (23 with squamous cell carcinoma, five with Bowen's disease, 72 with basal cell carcinoma, and 10 with other premalignant lesions). The age of the subjects ranged from 39 to 90 (average 68) years; 50 were men and 60 were women. The specimens were stored at $4^{\circ} \mathrm{C}$ until DNA

\section{Key points}

- The CCR2-64I allele conferred significant protection from breast cancer.

- The mutated CXCL12 allele conferred increased susceptibility to breast cancer.

- Polymorphisms in the CCR5 gene $(\Delta 32,59029 \mathrm{G}-\mathrm{A})$ showed no association with breast cancer.

- No association was found in the bladder and skin cancer groups with any of the chemokine polymorphism studied.

extraction. The diagnosis in all cases was histologically confirmed.

\section{Bladder cancer}

At the Department of Urology, University General Hospital of Heraklion, Greece, 68 tumour specimens were obtained from male patients aged 47-81 (average 66.6) years with histologically confirmed bladder cancer. The specimens were stored at $-80^{\circ} \mathrm{C}$ immediately after surgical removal, until DNA extraction.

\section{Control groups}

Blood samples were collected from 361 healthy donors aged 19-82 (average 49.1) years registered with a general practice in Athens, Greece. For the female breast cancer patients, 210 women aged 25-82 (average 53.5) years formed a control group; and for the male bladder cancer patients, 148 men aged 19-76 (average 44) years were controls. The total healthy population of 361 donors ( $58 \%$ women) formed a control group for the skin cancer patients ( $54 \%$ of these were women).

All subjects derived from a white Caucasian Greek population. All the cancer patients in the study had no family history of cancer and presented tumours which were characterised as sporadic primary. The Ethics Committee of the University of Crete approved this study and written informed consent was obtained from all donors. Genotyping of tumour suppressor genes from cancer tissues includes the risk of introducing artefacts because of the inherent genomic instability. Although none of the genes examined in the present study fell into the tumour suppressor gene category, to reduce even further the possibility of artefacts, in the cases where a blood sample was lacking the adjacent normal portion of the excised cancer tissue was used.

\section{DNA extraction and genotyping}

DNA extraction was carried out according to previously published methods. ${ }^{14}$ All specimens were examined for the presence of amplifiable DNA. In each PCR, two negative 
controls were employed to make sure that no contaminants were introduced in the initial PCR. The primers used in the study were:

- CCR5d32F: 5'-GTGGTGACAAGTGTGATCAC-3'

- CCR5d32R: 5'-TTGTAGGGAGCCCAGAAGAG-3'

- CXCli2f: 5'-CAGTCAACCTGGGCAAAGCC-3'

- CXCL12R: 5'-AgCTTTGgtCCTGAGAGTCC-3'

- CCR2F: 5'-TTGTGGGCAACATGATGG-3'

- CCR2R: 5'-CTGTGAATAATTTGCACATTGC-3'

- CCR5 59029F: 5'-CCCGTGAGCCCATAGTTAAAACTC-3'

- CCR5_59029R: 5'-TCACAGGGCTTTTCAACAGTAAGG-3'.

The reaction mixture consisted of PCR buffer, $1.5 \mathrm{mM}$ $\mathrm{MgCl}_{2}, 0.2 \mathrm{mM}$ of each dNTP, $0.5 \mathrm{mM}$ of each primer, and 1.2units/reaction Taq DNA polymerase (Invitrogen, Carlsbad, CA, USA). The reaction conditions were:

- for CCR5 $\Delta 32$, an initial denaturation at $94^{\circ} \mathrm{C}$ for three minutes, then 35 cycles at $92^{\circ} \mathrm{C}$ for 30 seconds, at $55^{\circ} \mathrm{C}$ for 30 seconds, at $72^{\circ} \mathrm{C}$ for 30 seconds, and finally extension at $72^{\circ} \mathrm{C}$ for 10 minutes ${ }^{15}$

- for CXCL12-3A, PCR conditions as above, with annealing temperature at $58^{\circ} \mathrm{C}$; PCR products were digested with 10 units $\mathrm{MspI} /$ reaction (NEBS) at $37^{\circ} \mathrm{C}$ for four hours ${ }^{16}$

- for CCR2-64I 3A, PCR conditions as above, with annealing temperature at $52^{\circ} \mathrm{C}$. The products were digested with lounits BSaBI /reaction (NEBS) at $60^{\circ} \mathrm{C}$ for four hours ${ }^{17}$
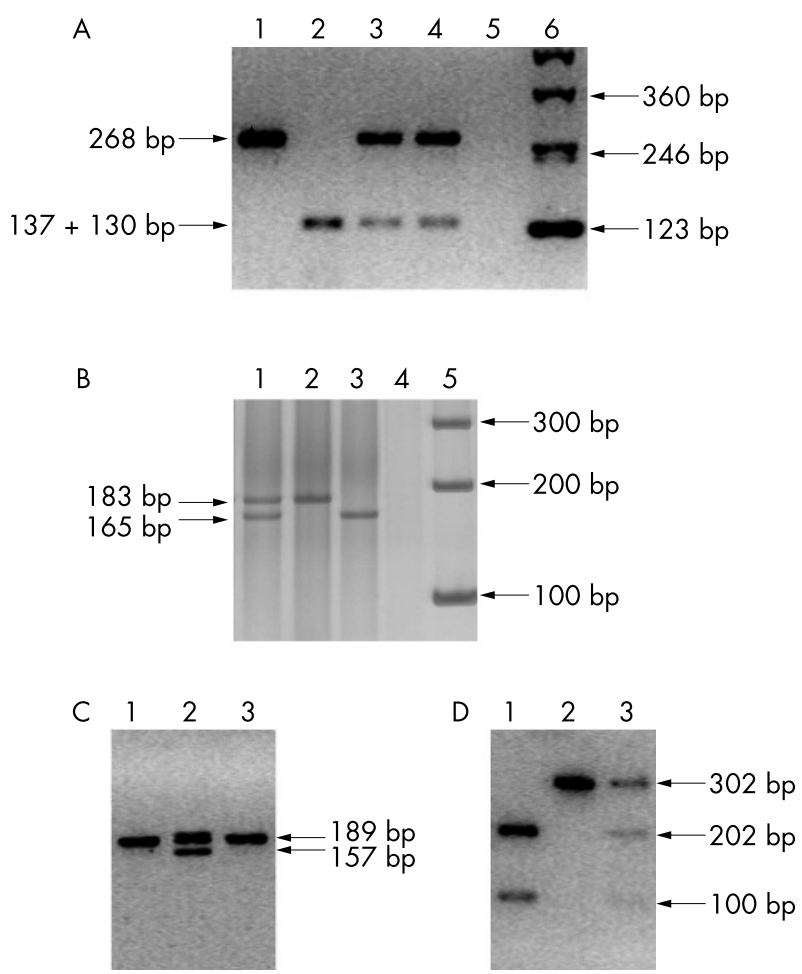

Figure 1 Representative samples from the RFLP genotype analysis. (A) Agarose electrophoresis for CCR5 59029 G-A. Samples: 1, wild type homozygote; 2 , mutated homozygote; 3-4, heterozygotes; 5 , negative control; 6, marker. (B) Acrylamide electrophoresis for CCR2-64I. Samples: 1, heterozygote; 2 , wild type homozygote $A ; 3$, mutated homozygote $G ; 4$, negative control; 5, marker. (C) Agarose electrophoresis for CCR5 $\Delta 32$. Samples: 1 and 3 wild type homozygote; 2, heterozygote. (D) Agarose electrophoresis for CXCL12-3A. Samples: 1, wild type homozygote; 2, mutated homozygote; 3 , heterozygote.
Table 1 Allelic and genotypic frequencies in the female control and female breast cancer patient groups

\begin{tabular}{|c|c|c|c|c|}
\hline Polymorphism & $\begin{array}{l}\text { Normal } \\
(\%)\end{array}$ & $\begin{array}{l}\text { Breast cancer } \\
(\%)\end{array}$ & \multicolumn{2}{|l|}{ Significance } \\
\hline \multicolumn{5}{|l|}{ CCR5 $\triangle 32$} \\
\hline Number of samples & 210 & 264 & & \\
\hline Wild/wild & $196(93.3)$ & $238(90.1)$ & $p=0.21$ & NO \\
\hline Wild/mutated & $14(6.7)$ & $26(9.9)$ & $\mathrm{df}=2$ & \\
\hline Mutated/mutated & 0 & 0 & & \\
\hline Allele frequency & 0.0333 & 0.0492 & $p=0.226$ & NO \\
\hline $\begin{array}{l}\text { Hardy-Weinberg } \\
\text { CXCL12 }\end{array}$ & YES & YES & $d f=1$ & \\
\hline Number of samples & 212 & 264 & & \\
\hline Wild/wild & $101(47.6)$ & $98(37.1)$ & $p=0.067$ & NO \\
\hline Wild/mutated & $92(43.3)$ & $136(51.5)$ & $d f=2$ & \\
\hline Mutated/mutated & 19 (8.96) & 30 (11.3) & & \\
\hline Allele frequency & 0.3066 & 0.3712 & $p=0.036$ & YES \\
\hline $\begin{array}{l}\text { Hardy-Weinberg } \\
\text { CCR2-64I }\end{array}$ & YES & YES & $d f=1$ & $>95 \%$ \\
\hline Number of samples & 211 & 264 & & \\
\hline Wild/wild & $154(73)$ & 221 (83.7) & $p=0.017$ & YES \\
\hline Wild/mutated & 50 (23.7) & $38(14.4)$ & $d f=2$ & $>95 \%$ \\
\hline Mutated/mutated & $7(3.3)$ & $5(1.9)$ & & \\
\hline Allele frequency & 0.1517 & 0.0909 & $p=0.004$ & YES \\
\hline $\begin{array}{l}\text { Hardy-Weinberg } \\
\text { CCR5 } 59029 \text { G-A }\end{array}$ & YES & YES & $d f=1$ & $>99 \%$ \\
\hline Number of samples & 177 & 264 & & \\
\hline Wild/wild & $46(25.99)$ & $60(22.7)$ & $p=0.236$ & NO \\
\hline Wild/mutated & $89(50.28)$ & $154(58.4)$ & $d f=2$ & \\
\hline Mutated/mutated & $42(23.73)$ & $50(18.9)$ & & \\
\hline Allele frequency & 0.4887 & 0.4811 & $p=0.823$ & NO \\
\hline Hardy-Weinberg & YES & YES & $d f=1$ & \\
\hline
\end{tabular}

- for CCR559029 G-A, PCR conditions as above, with annealing temperature at $60^{\circ} \mathrm{C}$. The reaction product was digested with lounits $\mathrm{BSp} 1286 \mathrm{I} /$ reaction (NEBS) at $37^{\circ} \mathrm{C}$ for five hours. ${ }^{13}$

All PCR samples with an undigested result were submitted to redigestion with 20 units/reaction of enzyme and overnight incubation.

The products of the digestion (CCR5 $\Delta 32$, CCR264I, and CXCL12-3A) were visualised by agarose gel electrophoresis (2\%) and ethidium bromide staining. The CCR5 59029 G-A digest was visualised in acrylamide gel electrophoresis and silver staining.

\section{Statistical analysis}

Genotype frequencies for each polymorphism were evaluated using the Hardy-Weinberg equilibrium test. Allele frequencies and the prevalence of genotypes were determined for the study and control groups and compared by the $\chi^{2}$ test. Furthermore, for each polymorphism the allele presence (homozygous or heterozygous) or absence, and the homozygosity (for either allele) or heterozygosity, were statistically determined. Statistical significance was defined as $\mathrm{p}<0.05$. All analyses were performed using SPSSvl0 (SPSS, Chicago, USA).

\section{RESULTS}

Table 1 summarises allelic and genotype frequencies for the breast cancer, table 2 for the bladder cancer, and table 3 for the non-melanoma skin cancer groups

\section{CCR5 $\triangle 32$ and CCR5-59029G}

Genotype frequency distributions were in agreement with the Hardy-Weinberg equilibrium in all sample groups. We established no statistically significant difference in allelic frequency or genotype frequency between the cancer groups and the corresponding control groups. 
Table 2 Allelic and genotypic frequencies in the male bladder cancer patient and male control groups

\begin{tabular}{|c|c|c|c|}
\hline Polymorphism & $\begin{array}{l}\text { Normal } \\
(\%)\end{array}$ & $\begin{array}{l}\text { Bladder cancer } \\
(\%)\end{array}$ & Significance \\
\hline \multicolumn{4}{|l|}{ CCR5 $\Delta 32$} \\
\hline $\begin{array}{l}\text { Number of } \\
\text { samples }\end{array}$ & 148 & 68 & \\
\hline Wild/wild & $127(85.8)$ & $58(85.3)$ & \multirow{2}{*}{$\begin{array}{l}\mathrm{p}=0.919 \mathrm{NO} \\
\mathrm{df}=2\end{array}$} \\
\hline $\begin{array}{l}\text { Wild/ } \\
\text { mutated }\end{array}$ & $21(14.2)$ & $10(14.7)$ & \\
\hline $\begin{array}{l}\text { Mutated / } \\
\text { mutated }\end{array}$ & 0 & 0 & \\
\hline Allele frequency & 0.0700 & 0.0735 & \multirow{3}{*}{$\begin{array}{l}\mathrm{p}=0.923 \mathrm{NO} \\
\mathrm{df}=1\end{array}$} \\
\hline $\begin{array}{l}\text { Hardy- } \\
\text { Weinberg }\end{array}$ & & & \\
\hline CXCL12 & & & \\
\hline $\begin{array}{l}\text { Number of } \\
\text { samples }\end{array}$ & 148 & 68 & \\
\hline Wild/wild & $67(45.3)$ & $31(45.5)$ & \multirow{2}{*}{$\begin{array}{l}\mathrm{p}=0.983 \mathrm{NC} \\
\mathrm{df}=2\end{array}$} \\
\hline Wild/mutated & 71 (48) & $32(47.05)$ & \\
\hline $\begin{array}{l}\text { Mutated/ } \\
\text { mutated }\end{array}$ & $10(9.7)$ & $5(7.35)$ & \\
\hline Allele frequency & 0.3074 & 0.3088 & \multirow{2}{*}{$\begin{array}{l}\mathrm{p}=0.976 \mathrm{NO} \\
\mathrm{df}=1\end{array}$} \\
\hline $\begin{array}{l}\text { Hardy-Weinberg } \\
\text { CCR2-64I }\end{array}$ & YES & YES & \\
\hline $\begin{array}{l}\text { Number of } \\
\text { samples }\end{array}$ & 148 & 68 & \\
\hline Wild/wild & $115(77.7)$ & $51(75)$ & \multirow{2}{*}{$\begin{array}{l}p_{1 f}=0.324 \mathrm{NO} \\
d f=2\end{array}$} \\
\hline Wild/mutated & $33(22.3)$ & $16(23.5)$ & \\
\hline $\begin{array}{l}\text { Mutated/ } \\
\text { mutated }\end{array}$ & $0(0)$ & $1(1.5)$ & \\
\hline Allele frequency & 0.1115 & 0.1324 & \multirow{2}{*}{$\begin{array}{l}\mathrm{p}=0.532 \mathrm{NO} \\
\mathrm{df}=1\end{array}$} \\
\hline $\begin{array}{l}\text { Hardy- } \\
\text { Weinberg }\end{array}$ & YES & YES & \\
\hline \multicolumn{4}{|l|}{ CCR5 59029} \\
\hline $\begin{array}{l}\text { Number of } \\
\text { samples }\end{array}$ & 126 & 68 & \\
\hline Wild/wild & 34 (27) & $11(16.1)$ & $p=0.130 \mathrm{NO}$ \\
\hline Wild/mutated & 55 (43.7) & $39(57.4)$ & $\mathrm{df}=2$ \\
\hline $\begin{array}{l}\text { Mutated/ } \\
\text { mutated }\end{array}$ & $37(29.3)$ & $18(26.5)$ & \\
\hline Allele frequency & 0.5119 & 0.5515 & $p=0.456 \mathrm{NO}$ \\
\hline $\begin{array}{l}\text { Hardy- } \\
\text { Weinberg }\end{array}$ & YES & YES & $d f=1$ \\
\hline
\end{tabular}

\section{CXCL12-3A}

Genotype frequency distributions were in agreement with the Hardy-Weinberg equilibrium in all sample groups. Comparison of each of the cancer groups with the corresponding control group showed significant differences in the breast cancer group in the allelic $(p=0.036$; $\mathrm{df}=1)$ and marginally non-significant in the genotypic $(p=0.067$; $\mathrm{df}=2$ ) frequencies. Statistical evaluation after genotype grouping showed a statistically significant difference between the control groups in the breast cancer $(\mathrm{p}=0.02 ; \mathrm{df}=1)$ and also in the non-melanoma skin cancer $(\mathrm{p}=0.032 ; \mathrm{df}=$ 1) groups when compared for the presence (CXCL12-3A/ CXCL12-3A, CXCL12-3A/wild) or the absence (wild/wild) of the allele. No other genotype grouping gave statistically significant results.

\section{CCR2-64I}

Genotype frequency distributions were in agreement with the Hardy-Weinberg equilibrium in all sample groups. Comparison of each of the cancer groups with the corresponding control showed significant differences in the breast cancer group both in the allelic $(\mathrm{p}=0.004 ; \mathrm{df}=1)$ and the genotypic ( $p=0.017 ; \mathrm{df}=2$ ) frequencies. Evaluation after genotype grouping showed a statistically significant difference in the breast cancer group when compared for the presence (CCR2-64I/CCR2-64I, CCR2-64I/wild) or the absence (wild/wild) of the allele $(\mathrm{p}=0.004 ; \mathrm{df}=1)$. The
Table 3 Allelic and genotypic frequencies in the skin cancer patient and control groups

\begin{tabular}{|c|c|c|c|c|}
\hline Polymorphism & $\begin{array}{l}\text { Normal } \\
\text { (\%) }\end{array}$ & $\begin{array}{l}\text { Skin cancer } \\
(\%)\end{array}$ & \multicolumn{2}{|l|}{ Significance } \\
\hline \multicolumn{5}{|l|}{ CCR5 $\Delta 32$} \\
\hline Number of & 361 & 110 & & \\
\hline Wild/wild & $326(90.3)$ & 103 (93.6) & $p=0.283$ & NO \\
\hline Wild/mutated & $35(9.6)$ & $7(6.4)$ & $d f=2$ & \\
\hline $\begin{array}{l}\text { Mutated/ } \\
\text { mutated }\end{array}$ & 0 & & & \\
\hline Allele frequency & 0.0484 & 0.0318 & $p=0.294$ & NO \\
\hline $\begin{array}{l}\text { Hardy- } \\
\text { Weinberg } \\
\text { CXCL12 }\end{array}$ & YES & YES & $\mathrm{df}=1$ & \\
\hline $\begin{array}{l}\text { Number of } \\
\text { samples }\end{array}$ & 363 & 110 & & \\
\hline Wild/wild & $169(46.5)$ & $64(58.1)$ & $p=0.097$ & NO \\
\hline Wild/mutated & $164(45.2)$ & $38(34.5)$ & $\mathrm{df}=2$ & \\
\hline $\begin{array}{l}\text { Mutated/ } \\
\text { mutated }\end{array}$ & $30(8.3)$ & $8(7.2)$ & & \\
\hline Allele frequency & 0.3085 & 0.2454 & $p=0.071$ & NO \\
\hline $\begin{array}{l}\text { Hardy- } \\
\text { Weinberg }\end{array}$ & YES & YES & $\mathrm{df}=1$ & \\
\hline CCR2-64I & & & & \\
\hline $\begin{array}{l}\text { Number of } \\
\text { samples }\end{array}$ & 362 & 110 & & \\
\hline Wild/wild & 271 (74.9) & 74 (67.3) & $p=0.234$ & NO \\
\hline Wild/mutated & $84(23.2)$ & $32(29.1)$ & $d f=2$ & \\
\hline $\begin{array}{l}\text { Mutated/ } \\
\text { mutated }\end{array}$ & 7 (1.9) & $4(3.6)$ & & \\
\hline Allele frequency & 0.1353 & 0.1818 & $p=0.087$ & NO \\
\hline $\begin{array}{l}\text { Hardy- } \\
\text { Weinberg } \\
\text { CCR5 } 59029 \\
\text { G-A }\end{array}$ & YES & YES & $d f=1$ & \\
\hline $\begin{array}{l}\text { Number of } \\
\text { samples }\end{array}$ & 306 & 110 & & \\
\hline Wild/wild & $80(26.1)$ & $29(26.4)$ & $p=0.720$ & NO \\
\hline Wild/mutated & $145(47.4)$ & $56(50.9)$ & $d f=2$ & \\
\hline $\begin{array}{l}\text { Mutated/ } \\
\text { mutated }\end{array}$ & $81(26.5)$ & 25 (22.7) & & \\
\hline $\begin{array}{l}\text { Allele frequency } \\
\text { Hardy- } \\
\text { Weinbera }\end{array}$ & $\begin{array}{l}0.5016 \\
\text { YES }\end{array}$ & $\underbrace{0.4818}_{\text {YES }}$ & $\begin{array}{l}\mathrm{p}=0.614 \\
\mathrm{df}=1\end{array}$ & NO \\
\hline
\end{tabular}

grouping of homozygotes (CCR2-64I/CCR2-64I, wild/wild) and heterozygotes (CCR2-64I /wild) showed a statistically significant difference $(p=0.009 ; \mathrm{df}=1)$. No other genotype grouping gave statistically significant results.

\section{DISCUSSION}

In the present study, we investigated the potential involvement of polymorphisms in the genes CCR5, CCR2, and CXCL12 as markers for genetic events contributing to the appearance of breast, bladder, and non-melanoma skin cancer. We observed a significant association for CXCL12 and CCR2 polymorphisms exclusively in breast cancer. The lack of association in the skin cancer and bladder cancer groups should be evaluated in view of the smaller population sample that was available. Our results demonstrate a complete linkage disequilibrium between the CCR5 59029 G allele, CCR5 $\triangle 32$, and CCR2-64I, in agreement with previously published findings. ${ }^{12} 13$

CXCL12 is the main ligand for CXCR4. CXCL12-3'A is a single base variant in the $3^{\prime}$ untranslated region of the CXCL12 gene, which initially was reported as a factor delaying AIDS progression to death especially in the late stages of HIV infection. ${ }^{16}$ Our data indicated a significant association in the allelic frequency of the CXCL12 polymorphism with breast cancer. Further genotype grouping revealed a significant preference for the presence of a mutated CXCL12 allele in the breast cancer group $(\mathrm{OR}=$ 1.54; $95 \%$ CI from 1.05 to 2.26 ). 
CCR2 is the only 7-transmembrane G protein-coupled receptor of CCL2. CCL2 is abundantly produced in a variety of inflammatory diseases, such as atherosclerosis and rheumatoid arthritis. The CCL2 gene is also expressed during the early stages of melanoma, and it is produced in metastatic lesions. CCR2-64I is an amino acid substitution in the transmembrane domain of CCR2. CCR2-46I has been investigated extensively in AIDS related studies and is believed to affect the availability of CCR5 through the formation of heterodimers. ${ }^{17}$ In our study, significant differences were determined when the genotype and allelic frequencies in the breast cancer and control groups were compared. Genotype grouping revealed significant breast cancer protection for the mutated allele $(\mathrm{OR}=0.53 ; 95 \% \mathrm{CI}$ from 0.33 to 0.84 ) and the heterozygote genotype $(\mathrm{OR}=$ $0.54 ; 95 \%$ CI from 0.33 to 0.89 ).

The CCR5 332 allele encodes a truncated product that is not expressed on the cell surface ${ }^{18}$ but remains in the endoplasmic reticulum. CCR5 $\Delta 32$ molecules are capable of forming heterocomplexes with normal CCR5 in heterozygous individuals, retaining normal CCR5 molecules in the endoplasmic reticulum and reducing cell surface expression of CCR5. ${ }^{19}$ In the present study, the CCR $5 \Delta 32$ allele had no association with any of the cancer groups studied. This could be attributed to the fact that we did not find any mutated homozygotes which, according to previous studies, exert the major functional defect. CCR5 59029G/A is an A versus G single nucleotide variant at base pair $59029 \mathrm{G}$ in the promoter region of the CCR5 gene. The G allele exhibits a 50\% lower expression of CCR5 in vitro, and confers slower AIDS progression than the A allele by 3.8 years (when comparing homozygous genotypes). Statistical analysis revealed no significant differences in the genotype and the allelic frequencies, concurring to an absence of involvement of CCR5, in agreement with the results on CCR5 $\Delta 32$.

Previous reports on AIDS related non-Hodgkin's lymphoma (NHL) demonstrated that the CXCL12-3'A chemokine variant was associated with approximate doubling of the NHL risk in heterozygotes and an approximately fourfold increase in homozygotes, whereas the CCR264I allele had no effect. ${ }^{20}$ The CCR5 $\Delta 32$ allele in homozygotes was highly protective against NHL. ${ }^{21}$ The proposed mechanism of CCR5- 432 protection against lymphoma was thought to involve reduced cell surface expression of CCR5 during the B cell transformation in NHL. Although our results with regard to CXCL12 in breast cancer agree, the mechanisms of chemokine involvement in NHL could be totally different, since NHL cells of lymphocytic origin are involved and it is well established that chemokines can have a direct effect on lymphocyte trafficking and development.

Chemokines are primarily responsible for leucocyte infiltration in cancer. ${ }^{22}$ Briefly, we can summarise the possible function of lymphocytes associated with tumours as two models. On one hand, they are a potential source of growth factors for tumour cells and angiogenic factors for endothelial cells. Recent reports on human tissues noted an association between the extent of macrophage infiltration of breast cancers and their degree of vascularity, which suggests that leucocytes may contribute to tumour angiogenesis and, hence, tumour survival. On the other hand, leukocytes associated with tumours may be residual evidence of the host's ineffective attempt to destroy the tumour immunologically. It was thought that by enhancing this response, tumour eradication could be initiated. Several chemokines have been used in animal models to elicit immune responses specific to tumours and resulting in tumour rejection. These include CCL2, ${ }^{23}$ CCL5, ${ }^{24}$ CCLl, ${ }^{25}$ CCL20, ${ }^{26}$ CCL $21,{ }^{27}$ CXCL10, ${ }^{28}$ and XCLl ${ }^{29}$

The relevance of chemokines to malignancy extends beyond their roles in leucocyte recruitment. Murine models show that chemokine secretion by tumour cells themselves may influence angiogenesis ${ }^{30}$ and tumour growth. ${ }^{31}$ There are also reports that some chemokines may act directly as growth factors on tumour cells. Recently, research has focused on the role of chemokines in protumourigenic activities and the secretion of proinflammatory cytokines that may facilitate breast cancer metastasis formation ${ }^{32}$ and contribute to disease progression..$^{33}$

In summary, chemokines have been heavily implicated in breast cancer during the later stages of cancer progression and metastasis. Our data indicate a possible role for CXCL12 and CCR2 in the initial stages of breast cancer. The minor dysfunction of the chemokine system caused by the polymorphisms, although not essential for survival, could be critical for immune surveillance and eradication of the spontaneously appearing transformed cells. Further studies in human and animal models are necessary to verify the above observation and establish a possible mechanism.

\section{ACKNOWLEDGMENTS}

We would like to thank $\mathrm{N}$ Soulitzis for help with the statistical analysis.

\section{Authors' affiliations \\ A Zafiropoulos*, N Crikas*, A M Passam, D A Spandidos, Laboratory of Virology, Medical School, University of Crete, Heraklion, Greece}

${ }^{*}$ Authors contributing equally to this study

Correspondence to: Prof. D A Spandidos, Laboratory of Virology, Medical School, University of Crete, Heraklion 71100, Crete, Greece; spandidos@spandidos.gr

\section{REFERENCES}

1 Gaki V, Tsopanomichalou M, Sourvinos G, et al. Allelic loss in chromosomal region 1q21-23 in breast cancer is associated with peritumoural angiolymphatic invasion and extensive intraductal component. Eur J Surg Oncol 2000;26(5):455-60.

2 Dialyna IA, Arvanitis DA, Spandidos DA. Genetic polymorphisms and transcriptional pattern analysis of CYPIAl, AhR, GSTM1, GSTPI and GSTT1 genes in breast cancer. Int J Mol Med $2001 ; 8(1): 79-87$.

3 de Jong MM, Nolte IM, te Meerman GJ, et al. Genes other than BRCAI and BRCA2 involved in breast cancer susceptibility. J Med Genet 2002;39(4):225-42.

4 Potocnik U, Ravnik-Glavac M, Golouh R, et al. Naturally occurring mutations and functional polymorphisms in multidrug resistance 1 gene: correlation with microsatellite instability and lymphoid infiltration in colorectal cancers. J Med Genet 2002;39(5):340-6.

5 del Pozo MA, Sanchez-Mateos P, Nieto M, et al. Chemokines regulate cellular polarization and adhesion receptor redistribution during lymphocyte interaction with endothelium and extracellular matrix. Involvement of cAMP signaling pathway. J Cell Biol 1995;131(2):495-508.

6 Melani C, Pupa SM. Stoppacciaro A, et al. An in vivo model to compare human leukocyte infiltration in carcinoma xenografts producing different chemokines. Int J Cancer 1995;62(5):572-8.

7 Hirose K, Hakozaki M, Nyunoya Y, et al. Chemokine gene transfection into tumour cells reduced tumourigenicity in nude mice in association with neutrophilic infiltration. Br J Cancer 1995:72(3):708-14.

8 Mellado M, de Ana AM, Moreno MC, et al. A potential immune escape mechanism by melanoma cells through the activation of chemokine-induced cell death. Curr Biol 2001;11(9):691-6.

9 Sozzani S, Introna M, Bernasconi S, et al. MCP-1 and CCR2 in HIV infection: regulation of agonist and receptor expression. J Leukoc Biol 1997;62(1):30-3.

10 Samson M, Labbe O, Mollereau C, et al. Molecular cloning and functional expression of a new human CC-chemokine receptor gene. Biochemistry 1996;35(11):3362-7

11 Arenberg DA, Kunkel SL, Polverini PJ, et al. Inhibition of interleukin-8 reduces tumourigenesis of human non-small cell lung cancer in SCID mice. J Clin Invest 1996;97(12):2792-802.

12 Smith MW, Dean M, Carrington $M$, et al. Contrasting genetic influence of CCR2 and CCR5 variants on HIV-1 infection and disease progression. Hemophilia Growth and Development Study (HGDS), Multicenter AIDS Cohort Study (MACS), Multicenter Hemophilia Cohort Study (MHCS), San Francisco City Cohort (SFCC), ALIVE Study. Science 1997;277(5328):959-65

13 McDermott DH, Zimmerman PA, Guignard F, et al. CCR5 promoter polymorphism and HIV-1 disease progression. Multicenter AIDS Cohort Study (MACS). Lancet 1998;352(9131):866-70. 
14 Saridaki Z, Liloglou T, Zafiropoulos A, et al. Mutational analysis of CDKN2A genes in patients with squamous cell carcinoma of the skin. Br J Dermatol 2003; 148(4):638-48.

15 Huang Y, Paxton WA, Wolinsky SM, et al. The role of a mutant CCR5 allele in HIV-1 transmission and disease progression. Nat Med 1996;2(11):1240-3.

16 Winkler C, Modi W, Smith MW, et al. Genetic restriction of AIDS pathogenesis by an SDF-1 chemokine gene variant. ALIVE Study, Hemophilia Growth and Development Study (HGDS), Multicenter AIDS Cohort Study (MACS), Multicenter Hemophilia Cohort Study (MHCS), San Francisco City Cohort (SFCC). Science 1998;279(5349):389-93.

17 Shieh B, Liau YE, Hsieh PS, et al. Influence of nucleotide polymorphisms in the CCR2 gene and the CCR5 promoter on the expression of cell surface CCR5 and CXCR4. Int Immunol 2000;12(9):1311-8.

18 Liu R, Paxton WA, Choe S, et al. Homozygous defect in HIV-1 coreceptor accounts for resistance of some multiply-exposed individuals to HIV-1 infection. Cell 1996;86(3):367-77.

19 Benkirane M, Jin DY, Chun RF, et al. Mechanism of transdominant inhibition of CCR5-mediated HIV-1 infection by ccr5delta32. J Biol Chem 1997;272(49):30603-6.

20 Rabkin CS, Yang Q, Goedert JJ, et al. Chemokine and chemokine receptor gene variants and risk of non-Hodgkin's lymphoma in human immunodeficiency virus-1-infected individuals. Blood 1999;93(6): 1838-42.

21 Dean $M$, Jacobson LP, McFarlane G, et al. Reduced risk of AIDS lymphoma in individuals heterozygous for the CCR5-delta32 mutation. Cancer Res 1999;59(15):3561-4.

22 Gerard C, Rollins BJ. Chemokines and disease. Nat Immunol 2001;2(2):108-15

23 Manome Y, Wen PY, Hershowitz A, et al. Monocyte chemoattractant protein1 (MCP-1) gene transduction: an effective tumour vaccine strategy for nonintracranial tumours. Cancer Immunol Immunother 1995;41(4):227-35.
24 Mule JJ, Custer M, Averbook B, et al. RANTES secretion by gene-modified tumour cells results in loss of tumourigenicity in vivo: role of immune cell subpopulations. Hum Gene Ther 1996;7(13): 1545-53.

25 Laning J, Kawasaki H, Tanaka $\mathrm{E}$, et al. Inhibition of in vivo tumour growth by the beta chemokine, TCA3. J Immunol 1994;153(10):4625-35.

26 Fushimi T, Kojima A, Moore MA, et al. Macrophage inflammatory protein 3 alpha transgene attracts dendritic cells to established murine tumours and suppresses tumour growth. J Clin Invest 2000;105(10):1383-93.

27 Vicari AP, Ait-Yahia S, Chemin K, et al. Antitumour effects of the mouse chemokine 6 Ckine/SLC through angiostatic and immunological mechanisms. $J$ Immunol 2000; 165(4):1992-2000.

28 Luster AD, Leder P. IP-10, a -C-X-C- chemokine, elicits a potent thymusdependent antitumour response in vivo. J Exp Med 1993;178(3):1057-65.

29 Emtage PC, Wan Y, Hitt $M$, et al. Adenoviral vectors expressing lymphotactin and interleukin 2 or lymphotactin and interleukin 12 synergize to facilitate tumour regression in murine breast cancer models. Hum Gene Ther 1999; 10(5):697-709

30 Strieter RM, Kunkel SL, Arenberg DA, et al. Interferon gamma-inducible protein 10 (IP-10), a member of the C-X-C chemokine family, is an inhibitor of angiogenesis. Biochem Biophys Res Commun 1995;210(1):51-7.

31 Addison CL, Arenberg DA, Morris SB, et al. The CXC chemokine, monokine induced by interferon-gamma, inhibits non-small cell lung carcinoma tumour growth and metastasis. Hum Gene Ther 2000;11(2):247-61.

32 Muller A, Homey B, Soto $\mathrm{H}$, et al. Involvement of chemokine receptors in breast cancer metastasis. Nature 2001;410(6824):50-6.

33 Azenshtein E, Luboshits G, Shina S, et al. The CC chemokine RANTES in breast carcinoma progression: regulation of expression and potential mechanisms of promalignant activity. Cancer Res 2002;62(4):1093-102.

34 Mira E, Lacalle RA, Gonzalez MA, et al. A role for chemokine receptor transactivation in growth factor signaling. EMBO Rep 2001;2(2):151-6. 